\title{
PENGOLAHAN KOPI SEBAGAI PRODUK KHAS DESA KEMBANG KUNING KECAMATAN SIKUR KABUPATEN LOMBOK TIMUR
}

\author{
Dining Aidil Candri ${ }^{1^{*}}$, Azmi Yunan Amri $^{2}$, Wibisono Setyoadi ${ }^{3}$, Putri Intan Sari ${ }^{4}$, lin Farliana ${ }^{5}$ \\ ${ }^{1}$ Program Studi Biologi, Fakultas Matematika dan IImu Pengetahuan Alam, Universitas Mataram \\ ${ }^{2}$ Fakultas Teknik, Universitas Mataram \\ ${ }^{3}$ Fakultas Ekonomi dan Bisnis, Universitas Mataram \\ ${ }^{4}$ Fakultas Peternakan, Universitas Mataram \\ ${ }^{5}$ Fakultas Pertanian, Universitas Mataram \\ ${ }^{*}$ Co-Author : aidilch@unram.ac.id
}

\begin{abstract}
ABSTRAK. Pengembangan produk ekowisata seperti penataan lingkungan, pembuatan spot foto, serta pengenalan kuliner khas Desa Wisata Wisata sangat penting dilakukan untuk menarik minat pengunjung dan meningkatkan penghasilan masyarakat dari sektor ini. Kuliner khas masyarakat seperti kopi khas Kembang Kuning perlu mendapatkan perhatian lebih untuk dikembangkan karena memiliki potensi sebagai salah satu produk unggulan masyarakat. Adapun kegiatan ini dilakukan bertujuan untuk membantu masyarakat dalam mengolah kopi, memperbaiki kualitas pengemasan, dan pemasaran. Kopi khas Desa Kembang Kuning, kecamatan Sikur, kabupaten Lombok Timur memiliki cita rasa yang beragam sesuai campurannya seperti kakao, beras, vanilla, jahe, dan original. Kegiatan yang dilakukan pada bulan Januari - Maret ini diharapkan dapat membantu masyarakat terutama dalam meningkatkan produksi dan pemasaran kopi khas Kembang Kuning melalui beberapa pelatihan yang diberikan kepada masyarakat, diantaranya yaitu pelatihan pengemasan dan pemasaran produk. Melalui kedua pelatihan ini diharapkan target pemasaran kopi khas Kembang Kuning ini akan semakin luas sehingga membuka peluang kepada masyarakat untuk menjadikannya salah satu produk utama sumber pendapatan masyarakat..
\end{abstract}

Kata Kunci: Kopi, Pengolahan, Pemasaran

\begin{abstract}
The development of ecotourism products such as the arrangement of the environment, making photo spots, as well as the introduction of culinary specialties of the Tourism Village Tourism is very important to attract the interest of visitors and increase people's income from this sector. Typical culinary community such as Kembang Kuning coffee needs to get more attention to be developed because it has the potential as one of the community's superior products. The activity is carried out aimed at helping the community in processing coffee, improving the quality of packaging, and marketing. The typical coffee of Kembang Kuning Village, Sikur sub-district, East Lombok regency has various flavors according to its mix such as cocoa, rice, vanilla, ginger, and original. The activities carried out in January - March are expected to be able to help the community, especially in increasing the production and marketing of the typical Kembang Kuning coffee through several trainings provided to the community, including training in packaging and product marketing. Through these two trainings, it is hoped that the marketing target for the typical Yellow Flower coffee will be wider so that it opens up opportunities for the community to make it one of the main products for the people's income.
\end{abstract}

Keywords: Coffee, Processing, Marketing) 


\section{PENDAHULUAN}

Desa Kembang Kuning merupakan desa yang sangat potensial khususnya di bidang wisata dan pertanian. Di bidang wisata, desa Kembang Kuning telah didaulat menjadi desa wisata terbaik di NTB. Penilaian ini hasil verifikasi dari Kementerian Pariwisata (kemenpar) RI beberapa waktu lalu. Selain itu, desa Kembang Kuning sudah lama mengembangkan konsep wisata desa. Begitu juga dengan tingkat pertisipasi masyarakat desa di sektor pariwisata ini pun sudah cukup tinggi. Tidak sedikit warga desa Kemang Kuning ini turut menjadi tour guide bagi setiap wisatawan yang datang, menyediakan homestay di rumah-rumah, serta turut menawarkan paket wisata lokal seperti produk dan kegiatan sehari-hari masyarakat. Produk wisata tersebut antara lain proses pembuatan kopi secara tradisional atau coffe process.

Produk kopi yang ditawarkan masyarakat desa Kembang Kuning memiliki cita rasa yang khas karena berasal dari perkebunan kopi masyarakat setempat dan masih diolah secara tradisional sehingga dapat digunakan sebagai salah satu sumber pendapatan masyarakat. Akan tetapi, dikarenakan target pemasaran kopi khas Kembang Kuning yang hanya menyasar wisatawan, produksi kopi oleh masyarakat tergolong rendah dan hanya diproduksi ketika ada wisatawan yang berkunjung. Hal ini menyebabkan produk kopi khas Kembang Kuning belum bisa menjadi produk yang dapat menyokong perekonomian masyarakat. Oleh karena itu, perlu dilakukan upaya untuk meningkatkan produksi dan pemasaran kopi khas Kembang Kuning dengan lebih baik.

Selama ini, promosi kopi khas Kembang Kuning masih sangat terbatas pada wisatawan yang datang sehingga kopi ini belum dikenal masyarakat di luar desa Kembang Kuning. Perbaikan pada sistem promosi dan pemasaran tentu sangat penting dilakukan. Mengacu pada hal tersebut, perlu dilakukan pelatihan kepada masyarakat mengenai sistem promosi dan pemasaran baik secara online maupun offline.

Adapun kegiatan pengabdian pada masyarakat ini memiliki tujuan utnuk memberikan pelatihan pengolahan kopi dengan berbagai varian rasa, pembaharuan kemasan agar lebih menarik, dan cara pemasaran yang lebih baik secara online maupun offline.

Selain itu, melalui kegiatan ini diharapkan dapat member manfaat berupa meningkatnya pengetahuan dan keterampilan masyarakat dalam pengolahan kopi dan pemasarannya sehingga dapat menjadi salah satu sumber pendapatan masyarakat dan juga sebagai produk ekowisata khas desa Kembang Kuning.

\section{ANALISIS PERMASALAHAN}

Masyarakat desa Kembang Kuning telah memiliki beberapa usaha industri dengan memanfaatkan hasil tani seperti kopi dan beras. Usahanya seperti pembuatan bubuk kopi dengan berbagai varian rasa atau campuran seperti menggunakan cokelat, beras, jahe dan original. Akan tetapi, pemasaran hasil produksi masyarakat dalam usaha ini hanya dalam ruang lingkup desa, yaitu dengan cara menjual ke para tamu wisatawan secara langsung. Hal ini menyebabkan hasil produksi kopi masyarakat terbilang rendah karena hanya diproduksi ketika para wisatawan datang. Sebagai akibat dari kondisi tersebut, masyarakat tidak dapat memanfaatkan pekerjaan ini secara tetap.

\section{SOLUSI YANG DITAWARKAN}

Sebagai solusi untuk mengatasi permasalahan di atas, maka perlu dilakukan upaya peningkatan pemasaran kopi desa Kembang Kuning. Upaya tersebut dapat dimulai dengan 
melakukan sosialisasi wisata berbasis ekowisata kepada masyarakat, peningkatan penerapan iptek, serta melatih masyarakat melakukan pengemasan dan pemasaran kopi dengan lebih baik sehingga dapat meningkatkan nilai jual dan pemasukan yang didapatkan masyarakat Kembang Kuning melalui industry kopi rumahan tersebut.

Target luaran dari kegiatan pengabdian ini yaitu masyarakat desa Kembang Kuning mampu mengembangkan pengolahan kopi sebagai penunjang ekowisata di Desa Kembang Kuning, meningkatkan kualitas produk melalui teknik pengemasan, serta memasarkan kopi dengan baik secara online maupun offline.

\section{METODE}

Kegiatan pelatihan pengolahan kopi ini dilaksanakan di desa kembang Kuning, Kecamatan Sikur, Lombok Timur pada Januari-Maret 2019. Peserta dalam kegiatan pelatihan ini adalah ibu-ibu PKK, perwakilan masyarakat masing-masing dusun di Desa Kembang Kuning, pemuda/ karang taruna, pokdarwis, dan sebagainya. Berikut merupakan beberapa tahapan kegiatan yang dilakukan dalam pengabdian ini, antara lain:

\section{Pra Kegiatan}

Proses pra-kegiatan terdiri atas persiapan, konsolidasi tim, dan observasi lapangan. Persiapan terdiri atas penyelesaian urusan administrasi baik dari pihak Universitas Mataram maupun pihak Pemerintah Desa Kembang Kuning, komunikasi awal dengan kelompok sasaran, diskusi kegiatan, serta penetapan teknik, metode, serta instrument yang akan digunakan selama kegiatan pengabdian.

Konsolidasi tim dilakukan untuk memastikan kesiapan tim terhadap tugas dan peranan masingmasing, serta penentuan jadwal pelaksanaan kegiatan. Proses terakhir pra-kegiatan adalah observasi lapangan yang bertujuan untuk mendapatkan informasi secara langsung kondisi masyarakat dan lingkungan di desa Kembang Kuning, dengan demikian dapat ditentukan sistem pelaksanaan kegiatan pengabdian yang tepat untuk diterapkan di masyarakat setempat. Beberapa informasi yang perlu dikumpulkan melalui observasi lapangan antara lain potensi kopi yang dihasilkan, pengolahan kopi yang dilakukan oleh masyarakat, serta potensi ekowisata Desa Kembang Kuning.

2. Sosialisasi wisata berbasis ekowisata

Kegiatan Sosialaisasi ini bertujuan untuk meningkatkan kesadaran dan pemahaman masyarakat terhadap wisata yang berbasis ekowisata karena kondisi lingkungan dan potensi desa yang mendukung untuk ekowisata yaitu air terjun dan sawah menghijau. Sosialisasi dilakukan pada Jumat 15 Maret 2019 di Bunga Homestay milik salah seorang warga Desa Kembang Kuning. Kegiatan ini dihadiri oleh pemuda desa, karang taruna, staf desa, pegiat usaha, dan masyarakat lainnya.

3. Penerapan iptek dan pelatihan

Kegiatan inti dari pengabdian ini adalah untuk melatih masyarakat dalam mengembangkan produk kopi masyarakat serta melakukan sistem pemasaran yang tepat. Terdapat beberapa proses dalam pelatihan ini yaitu pengemasan kopi sekaligus pembuatan brand dan desain kemasan, kemudian dilanjutkan dengan pemasaran kopi tersebut di outlet-outlet yang telah diusahakan maupun secara online. Penerapan iptek dilakukan dengan cara pendekatan kepada masyarakat kemudian memberikan pemahaman melalui diskusi santai. Adapun pelatihan yang 
dilakukan langsung menyasar kepada masyarakat yang terlibat langsung dalam pengolahan hingga pemasaran kopi.

\section{HASIL DAN PEMBAHASAN}

Upaya peningkatan perekonomian masyarakat desa Kembang Kuning melalui pengolahan dan pemasaran kopi menjadi topik utama yang diusung dalam kegiatan pengabdian kepada masyarakat ini. Kopi yang merupakan salah satu hasil perkebunan masyarakat desa Kembang Kuning dimanfaatkan sebagai salah satu produk ekowisata khas desa tersebut. Hal ini diupayakan melalui peningkatan kualitas produk, pengemasan, serta pemasaran yang tepat.

Sebelum dilaksanakannya pelatihan kepada masyarakat, perlu dilakukan beberapa tahap yang meliputi persiapan dan penyuluhan. Tahapan persiapan bertujuan untuk mempersiapakan segala hal terkait dengan kegiatan penyuluhan serta pelatihan, meliputi pengurusan administrasi dan observasi lapangan (Syaputra et al, 2019). Mayoritas masyarakat desa Kembang Kuning merupakan petani yang belum terlalu familiar dengan konsep Ekowisata. Oleh karena itu dibutuhkan peningkatan pemahaman masyarakat mengenai konsep tersebut melalui sosialisasi wisata berbasis ekowisata.

Kegiatan Sosialisasi ini bertujuan untuk meningkatkan kesadaran dan pemahaman masyarakat terhadap wisata yang berbasis ekowisata karena kondisi lingkungan dan potensi desa yang mendukung untuk ekowisata yaitu air terjun dan sawah menghijau. Sosialisasi dilakukan pada Jumat 15 Maret 2019 di Bunga Homestay milik salah seorang warga Desa Kembang Kuning. Kegiatan ini dihadiri oleh pemuda desa, karang taruna, staf desa, pegiat usaha, dan masyarakat lainnya. Beberapa poin yang disampaikan dalam sosialisasi tersebut antara lain: pengenalan keberadaan atraksi-atraksi wisata di Desa Kembang Kuning seperti air terjun, persawahan, spot foto, termasuk pula produk asli desa seperti kopi, beserta upaya peningkatan kualitasnya sehingga dapat menarik wisatawan.

Peningkatan kualitas dan produksi kopi oleh masyarakat Desa Kembang Kuning diusahakan melalui pelatihan dan penerapan iptek dalam kegiatan pengolahan dan pemasaran kopi tersebut. Peningkatan penerapan iptek di masyarakat dikhususkan pada kegiatan pengolahan kopi, pengemasan produk, serta pemasaran berbasis teknologi. Kegiatan ini dilaksanakan dengan cara pendekatan kepada masyarakat kemudian memberikan pemahaman melalui diskusi santai diikuti dengan pelatihan yang ditujukan kepada masyarakat.

Adapun proses pembuatan kopi hingga pengemasan yang dilakukan oleh masyarakat Kembang Kuning masih berlangsung secara manual atau dilakukan secara langsung. Tahapantahapan pembuatan kopi yang dilakukan antara lain pemilihan biji kopi, proses sangrai, penumbukan, proses penyaringan, pengemasan, dan pemasaran.

Pemilihan biji kopi dilakukan secara manual, yaitu dengan hanya mengambil biji kopi yang bagus untuk pembuatan kopi yang lebih berkualitas. Biji kopi terpilih kemudian disangrai bersama dengan beras atau bahan tambahan lain seperti kakao (biji cokelat), vanilla, dan jahe, tergantung pada varian rasa yang ingin dibuat. Proses sangrai dilakukan dengan menggunakan kete (alat sangrai yang terbuat dari tanah liat) dan kayu bakar. Selanjutnya, setelah selesai disangrai, kopi 
tersebut ditumbuk hingga halus dengan lesung, kemudian disaring. Kopi yang telah disaring dilanjutkan ke tahap pengemasan sebelum kemudian dijual atau dipasarkan.

Pengemasan atau packaging dilakukan untuk memperbaiki kualitas produk sehingga menjadi lebih menarik minat konsumen. Sebelum dilakukan pengemasan, terlebih dahulu dilakukan pembuatan desain kemasan yang akan digunakan, termasuk desain logo produk. Logo produk dan desain kemasan yang digunakan merupakan desain yang telah disepakati oleh masyarakat. Desain kemasan yang dibuat merupakan desain kemasan yang memungkinkan kopi terlihat dari luar plastik walaupun bungkus tidak dibuka. Hal ini diharapkan dapat menarik minat konsumen setelah dipasarkan nanti. Adapun logo produk yang disepakati menggunakan brand Cocokopi. Penentuan brand ini diharapkan dapat memudahkan konsumen dalam mengenali produk kopi dari desa Kembang Kuning ini.

Setelah dilakukan pelatihan pengemasan, pelatihan selanjutnya adalah pemasaran produk Cocokopi kepada konsumen. Pemasaran dilakukan dengan beberapa cara yaitu dengan menitipkan di pusat perbelanjaan oleh-oleh di Kota Mataram dan dipasarkan di sosial media seperti instagram. Selain itu, untuk menarik minat pembeli dilakukan juga pembuatan video promosi yang didukung juga oleh pihak desa.

Pelatihan pengemasan yang pemasaran yang dilakukan sangat disambut baik oleh masyarakat. Terlihat pada antusiasme peserta yang mengikuti pelatihan tersebut. Dalam menjalankan usaha yang mengedepankan kekhasan suatu daerah, maka proses pembuatan kopi khas tersebut tentunya harus selalu mengikuti tradisi pembuatan yang telah ada sebelumnya. Hal ini merupakan salah satu upaya yang dilakukan untuk menjaga kekhasan cita rasa produk kopi yang dihasilkan, selain juga menjadi atraksi wisata yang bisa ditawarkan kepada wisatawan terutama wisatawan asing. Oleh karena itu, diperlukan pengawasan terutama pada tahap pembuatan kopi untuk menjaga kualitas kopi yang dihasilkan. Pemasaran kopi yang berkualitas baik sangat didukung oleh pengemasan yang menarik serta keluasan cakupan pemasaran yang dimiliki. Pemerintah daerah dalam hal ini perlu memberikan dukungan yang besar kepada masyarakat terutama dalam proses peningkatan produksi masyarakat serta pengenalan produk daerah ke ruang lingkup pemerintahan yang lebih tinggi.

\section{KESIMPULAN}

Desa Kembang kuning, Kecamatan Sikur, Kabupaten Lombok Timur memiliki produk kopi tradisional dengan cita rasa yang khas sehingga dapat menjadi salah satu produk wisata yang ditawarkan oleh desa wisata ini. Proses pembuatan kopi khas desa kembang kuning ini masih dilakukan secara tradisional yaitu mulai dari pemilihan biji, proses sangrai, proses penumbukan, proses pengemasan dan proses pemasaran. Sebagai upaya meningkatkan pendapatan dari kopi khas ini, pelatihan pengemasan dan pemasaran dilakukan secara langsung kepada masyarakat. Respon masyarakat sangat positif dalam kegiatan ini dilihat dari dukungan dan antusiasme masyarakat mengikuti pelatihan.

Adapun saran dari kegiatan ini antara lain perlu adanya dukungan pemerintah daerah untuk meningkatkan promosi terutama fasilitas pariwisata desa Kembang Kuning sehingga dapat menarik wisatawan untuk datang. Wisatawan yang berkunjung ke desa ini merupakan salah satu target 
pemasaran kopi yang paling baik. Selain itu, perlu juga dilakukan pengenalan produk kopi khas desa Kembang Kuning dalam bazaar atau event-event baik bertaraf regional maupun nasional sehingga produk ini dapat dikenal lebih luas oleh masyarakat Indonesia.

\section{DAFTAR PUSTAKA}

Meiri, Anggi, dkk. 2013. "Analisis Perdagangan kopi Indonesia dipasar Internasional". Jurnal Tanaman Industri Dan Penyegar. 4(01): 39-46.

Novitasari, Irma. 2010. Proses Pengolahan Kopi Bubuk (Campuran Arabika dan Robusta) Serta Perubahan Mutunya Selama Penyimpanan. Bogor: Institut Pertanian Bogor.

Purba, Okta Maujana, dkk. 2012. "Prokdutivitas kopi arabika rakyat ( Coffea Arabica L.) di Kecamatan Raya, Kabupaten Simalungun". Jurnal Indexed. 1(02): 1-11.

Sariva, Oriza, dkk. 2014. "Karakteristik fisik buah kopi, kopi beras dan hasil olahan kopi rakyat di desa Sindang Jati, Kabupaten Rejang Lebong". Jurnal Agro Industri. 4(2): 65-77.

Wahyuni, Eka, dkk. 2013. "Analisis cita rasa kopi arabika organic pada beberapa ketinggian tempat dan cara pengolahannya di dataran tinggi gayo". Jurnal Menajemen Sumber Daya Lahan. 2(03) : 261-269. 